\title{
APBN 2020: ANALISIS KINERJA PENDAPATAN NEGARA SELAMA PANDEMI COVID-19
}

\author{
Muhammad Hamdan Sayadi \\ Universitas Indo Global Mandiri
}

Alamat Korespondensi:

hamdansayadi@uigm.ac.id

\begin{abstract}
The Government has reduced the State Revenue and Expenditure Budget of 2020 twice through Presidential Regulation No 54 and 72 of 2020 replacing Act No 20 of 2019 about the State Revenue and Expenditure Budget. The amount of the decline of state revenue budget through the presidential regulation is Rp533,25 trillion. The decline of state revenue budget twice shows an indication of the decline of state revenue performance of 2020 because of the Covid-19 pandemic. This paper aims to analyze the performance of country income of the Republic of Indonesia during the Covid-19 pandemic in 2020. This paper used descriptive statistics as a data analysis technique based on the variance analysis of income budget and analysis of income growth. The results showed that the performance of state income during the Covid-19 pandemic in 2020 decreased quite significantly from the same period in 2019. Income budget realization in 2020 decreased by 16,53 percent or Rp323,61 trillion from the same period in 2019. If the income budget realization is observed in detail, the realization of tax revenue decreased by 19,67 percent and non-tax revenue decreased by 16,42 percent.
\end{abstract}

Keywords:

Budget, Realization, State Revenue Performance, Revenue Growth Analysis

\begin{abstract}
ABSTRAK
Pemerintah menurunkan target Anggaran Pendapatan dan Belanja Negara untuk tahun 2020 sebanyak dua kali melalui Perpres No 54 dan 72 Tahun 2020 yang menggantikan UU No 20 Tahun 2019 tentang APBN. Total penurunan anggaran pendapatan negara melalui dua Perpres tersebut ialah sebesar Rp533,25 triliun. Penurunan anggaran pendapatan negara sebanyak dua kali menunjukkan sinyal awal menurunnya kinerja pendapatan negara pada tahun 2020 akibat pandemi Covid-19. Penelitian ini bertujuan untuk menganalisis kinerja pendapatan negara Republik Indonesia selama pandemi Covid-19 periode tahun 2020. Teknik analisis data yang digunakan dalam penelitian ini ialah statistik deskriptif berdasarkan analisis varians (selisih) anggaran pendapatan dan analisis pertumbuhan pendapatan. Hasil penelitian menunjukkan bahwa kinerja pendapatan negara selama pandemi Covid-19 tahun 2020 mengalami penurunan yang cukup signifikan bila dibandingkan pada periode yang sama tahun sebelumnya. Realisasi pendapatan negara tahun 2020 tumbuh negatif $16,53 \%$ atau terjadi penurunan realisasi sebesar Rp323,61 triliun bila dibandingkan pada periode yang sama tahun sebelumnya. Bila realisasi pendapatan negara dilihat lebih dalam, penurunan realisasi terjadi baik pada realisasi penerimaan pajak maupun realisasi Penerimaan Negara Bukan Pajak (PNBP). Realisasi penerimaan pajak pada tahun 2020 tumbuh negatif 19,67\% dan realisasi PNBP -16,42\% dibanding tahun 2019.
\end{abstract}

Kata Kunci:

Anggaran, Realisasi, Kinerja Pendapatan Negara, Analisis Pertumbuhan Pendapatan

KLASIFIKASI JEL:

H11

CARA MENGUTIP:

Sayadi, M. H. (2021). APBN 2020: Analisis kinerja pendapatan negara selama pandemi covid-19. Indonesian Treasury Review: Jurnal Perbendaharaan, Keuangan Negara dan Kebijakan Publik, 6(2), 159-171. 


\section{PENDAHULUAN}

\section{Latar Belakang}

Menurut Undang-Undang Nomor 17 Tahun 2003 dikatakan bahwa "Keuangan negara adalah semua hak dan kewajiban negara yang dapat dinilai dengan uang, serta segala sesuatu baik berupa uang maupun barang yang dapat dijadikan milik negara berhubung pelaksanaan hak dan kewajiban tersebut". Keuangan negara merupakan sumber ekonomi yang mendukung pemerataan pembangunan dan menciptakan stabilitas ekonomi, sosial, dan politik (Sulistyo, 2018). Keuangan negara identik dengan anggaran belanja dan anggaran pendapatan serta pembiayaan yang tercantum dalam APBN.

Menurut Pasal 12 Undang-Undang Nomor 17 Tahun 2003 "APBN disusun sesuai dengan kebutuhan penyelenggaraan pemerintahan negara dan kemampuan dalam menghimpun pendapatan negara". Pemerintah pusat memiliki hubungan yang sangat erat dengan pemerintah daerah. Beberapa pemerintah daerah masih memiliki tingkat ketegantungan sangat tinggi kepada pemerintah pusat berupa pendapatan transfer. Zukhri (2020) menyatakan bahwa salah satu daerah yang memiliki tingkat ketergantungan sangat tinggi kepada pemerintah pusat ialah Provinsi Kepulauan Bangka dengan tingkat ketergantungan keuangan diatas 50 persen, yaitu diantara 61,05-68,41 persen. Bila realisasi pendapatan negara mengalami penurunan, maka pendapatan daerah berupa bantuan pemerintah pusat juga akan berkurang.

DPR akan mempertimbangkan usulan dari pemerintah mengenai alokasi anggaran jika diperkirakan surplus. Sementara, jika defisit akan ditanggulangi dengan mencari dana lainnya sesuai dengan peraturan yang berlaku. Kinerja pemerintah dapat diukur melalui laporan realisasi APBN yang terpublikasi.

"Anggaran dalam pemerintahan merupakan tulang punggung (backbone) penyelenggaraan pemerintahan" (Mahmudi, 2019, hal.133). Kinerja keuangan pemerintah pusat dapat dianalisis dengan menggunakan analisis pendapatan, analisis belanja, dan analisis pembiayaan.

Salah satu unsur penting yang harus dianalisis dalam laporan realisasi APBN ialah selisih antara anggaran dan realisasi pendapatan negara. Pemerintah melalui Kementerian Keuangan harus dapat merealisasikan anggaran pendapatan negara yang telah disusun dan disahkan. Apabila pemerintah mampu merealisasikan anggaran

\section{PENERAPAN DALAM PRAKTIK}

- Penerimaan pajak yang mampu tumbuh positif hanya $\mathrm{PPh}$ pasal 25/29 orang pribadi dengan pertumbuhan 2,94\% atau sekitar Rp0,33 triliun yang dipengaruhi oleh WP OP mengalami peningkatan dalam hal kepatuhan yang dikelola dan diawasi oleh Direktorat Jenderal Pajak.

- Satu-satunya PNBP yang tumbuh positif ialah pendapatan BLU dengan pertumbuhan sebesar $33,49 \%$ atau sekitar Rp16,11 triliun.

- Pemerintah bisa lebih fokus pada peningkatan kepatuhan wajib pajak untuk meningkatkan penerimaan pajak selain PPh pasal 25/29 orang pribadi.

- Pemerintah bisa melakukan kajian dan penelitian terhadap komponen pada pendapatan BLU yang naik sangat signifikan meskipun dalam keadaan pandemi Covid-19.

pendapatan negara, maka kinerjanya tergolong baik. Namun jika realisasi pendapatan negara dibawah anggaran, maka kinerjanya tergolong kurang baik bahkan dapat dikategorikan buruk.

Mahmudi (2019, hal. 136) menyatakan bahwa "apabila target pendapatan dapat dicapai bahkan terlampaui, maka hal itu tidak terlalu mengejutkan karena memang seharusnya demikian dan jika target pendapatan tidak tercapai, hal ini butuh penelaahan lebih lanjut terkait dengan penyebab tidak tercapainya target".

Bidang akuntansi sektor publik, khususnya mengenai anggaran dan realisasi mengenal sebutan selisih lebih dan selisih kurang. Favourable variance sering digunakan sebagai pengganti istilah selisih lebih dan unfavourable variance sebagai selisih kurang.

Tabel 1 menunjukkan perkembangan pendapatan negara Republik Indonesia pada tahun 2015 - 2019. Persentase realisasi pendapatan negara terhadap anggaran dari tahun 2015 - 2018 selalu mengalami peningkatan, di mana pada tahun 2015 sebesar 85,60\% dan meningkat menjadi $87,11 \%$ pada tahun 2016. Pada tahun 2017 dan 2018 kembali mengalami peningkatan menjadi 95,99\% dan 102,58\%. Tetapi pada tahun 2019 persentase realisasi pendapatan negara terhadap anggaran mengalami penurunan menjadi $90,56 \%$.

Secara umum kinerja pendapatan negara dari tahun 2015 - 2019 masih kurang memuaskan karena hanya pada tahun 2018 realisasi yang melampaui target anggaran. Pertumbuhan 
realisasi pendapatan negara juga selalu mengalami peningkatan dari tahun 2015 - 2019. Pada tahun 2016 mengalami peningkatan sebesar Rp47,91 triliun dari tahun 2015. Pada tahun 2016 dan 2017 juga mengalami peningkatan sebesar Rp110,44 triliun dan Rp277,31 triliun. Peningkatan kembali terjadi pada tahun 2019 sebesar Rp16,95 triliun dari tahun 2018.

Kinerja pendapatan negara yang selalu meningkat dari tahun 2015 - 2019 sepertinya sulit dipertahankan pada tahun 2020. Alasan utama ialah wabah Covid-19 mengakibatkan ketidakpastian perekonomian global. Prospek ekonomi global juga berada pada kondisi ketidakpastian sebagai dampak dari ketidakpastian pasar keuangan dan perekonomian. Dalam merespon prospek pelemahan ekonomi global tersebut, pemerintah Republik Indonesia telah melakukan berbagai kebijakan dan langkahlangkah yang diperlukan, salah satunya dengan menerbitkan Perpres No 72 Tahun 2020. Terdapat perubahan rincian dan postur APBN dalam Perpres tersebut.

Pemerintah menurunkan target anggaran pendapatan negara untuk tahun 2020 sebanyak dua kali melalui Perpres No 54 dan 72 Tahun 2020 yang menggantikan UU No 20 Tahun 2019 tentang APBN. Anggaran awal pendapatan negara yang terdapat pada UU No 20 Tahun 2019 tentang APBN ialah sebesar Rp2.233,20 triliun. Jumlah tersebut turun menjadi Rp1.760,89 triliun pada Perpres No. 54 Tahun 2020 dan Rp1.699,95 triliun pada Perpres No. 72 Tahun 2020. Total penurunan anggaran pendapatan negara melalui dua Perpres tersebut ialah sebesar Rp533,25 triliun. Penurunan anggaran pendapatan negara sebanyak dua kali menunjukkan sinyal awal menurunnya kinerja pendapatan negara pada tahun 2020 akibat pandemi COVID-19.
Penulis tertarik mengkaji lebih dalam tentang APBN dan menganalisis kinerjanya selama pandemi Covid-19 terutama analisis terhadap realisasi pendapatan negara menggunakan metode analisis varians (selisih) anggaran pendapatan dan analisis pertumbuhan pendapatan dari sisi mikro dan analisis pertumbuhan ekonomi dari sisi makro. Berdasarkan permasalahan yang telah diuraikan maka rumusan masalah dalam penelitian ini ialah bagaimanakah kinerja keuangan pemerintah selama pandemi Covid-19 periode Januari-Agustus tahun 2020 dari sisi ekonomi mikro dan ekonomi makro?.

\section{LANDASAN TEORI}

\section{Anggaran Pendapatan dan Belanja Negara (APBN)}

Menurut UU Nomor 17 Tahun 2003 "APBN adalah rencana keuangan tahunan pemerintahan negara yang disetujui oleh Dewan Perwakilan Rakyat (DPR) dan wujud pengelolaan keuangan negara yang ditetapkan tiap tahun dengan undangundang. APBN terdiri atas anggaran pendapatan, anggaran belanja, dan pembiayaan".

Halim \& Kusufi (2014, hal 15) mengungkapkan bahwa APBN merupakan kekayaan negara yang dikelola langsung dan termasuk dalam pengurusan umum/administratif. Fungsi anggaran antara lain: kebijakan yang telah disahkan dan digunakan dapat dikontrol masyarakat mengenai apakah hal tersebut sesuai dengan peraturan yang berlaku atau tidak dan anggaran dapat digunakan atau dijadikan bahan utama dalam pengelolaan kekayaan negara.

Anggaran harus mampu diserap secara optimal yang menunjukkan capaian dari estimasi anggaran selama periode waktu tertentu. Menurut Nugroho \& Ananda (2012) anggaran dapat diserap secara optimal jika pekerjaan telah dilaksanakan dan

Tabel 1 Perkembangan Realisasi Pendapatan Negara Tahun 2015 - 2019

\begin{tabular}{|c|c|c|c|c|c|}
\hline \multirow{3}{*}{ Tahun } & \multicolumn{2}{|c|}{ Pendapatan Negara } & \multirow{3}{*}{$\begin{array}{c}\% \\
\text { terhadap } \\
\text { APBN }\end{array}$} & \multirow{2}{*}{\multicolumn{2}{|c|}{$\begin{array}{c}\text { Pertumbuhan Realisasi } \\
\text { Pendapatan Negara }\end{array}$}} \\
\hline & Anggaran & Realisasi & & & \\
\hline & \multicolumn{2}{|c|}{ (Dalam Triliun Rupiah) } & & $\begin{array}{l}\text { Triliun } \\
\text { Rupiah }\end{array}$ & $\%$ \\
\hline 2015 & $1.761,64$ & $1.508,02$ & $85,60 \%$ & - & - \\
\hline 2016 & $1.786,22$ & $1.555,93$ & $87,11 \%$ & 47,91 & $3,18 \%$ \\
\hline 2017 & $1.736,06$ & $1.666,37$ & $95,99 \%$ & 110,44 & $7,10 \%$ \\
\hline 2018 & $1.894,72$ & $1.943,68$ & $102,58 \%$ & 277,31 & $16,64 \%$ \\
\hline 2019 & $2.165,11$ & $1.960,63$ & $90,56 \%$ & 16,95 & $0,87 \%$ \\
\hline
\end{tabular}


dieksekusi berdasarkan dokumen perencanaan yang dibuat. Jika penyerapan anggaran tidak optimal, penilaian masyarakat terhadap pemerintah akan menghasilkan penilaian kinerja yang kurang baik.

Penyerapan anggaran yang kurang optimal dapat disebabkan oleh beberapa faktor. Rahim \& Saputra (2018), Kuswoyo (2012), Herriyanto (2012), Adrianus Dwi Siswanto \& Sri Lestari Rahayu (2010), Baridwan (2012), Setyawan (2017) mengungkapkan beberapa faktor yang menjadi penyebab keterlambatan penyerapan anggaran belanja APBN pada satuan kerja lingkup Provinsi Sumatera Barat seperti faktor proses lelang dan pengadaan barang dan jasa, faktor perubahan kebijakan internal satuan kerja dan kementerian/lembaga, faktor administrasi perencanaan anggaran, faktor pejabat perbendaharaan, faktor perubahan kebijakan pemerintahan, dan faktor verifikasi dokumen untuk pelaksanaan anggaran.

Faktor lainnya yang dapat menyebabkan penyerapan anggaran menjadi tidak optimal ialah terjadinya wabah atau pandemi yang menyebar tidak hanya dalam suatu kawasan tertentu tetapi di seluruh dunia. Apabila penyerapan anggaran optimal, pemerintah dapat mengalokasikan anggaran untuk menstimulus yang dapat mendorong pertumbuhan ekonomi.

\section{Pendapatan}

Peraturan Pemerintah No 71 Tahun 2010 tentang Standar Akuntansi Pemerintah membagi pendapatan menjadi 3, yaitu: pendapatan-LRA, pendapatan-LO, dan pendapatan transfer. Pendapatan-LRA berkaitan dengan "Semua penerimaan Rekening Kas Umum Negara/Daerah yang menambah Saldo Anggaran Lebih dalam periode tahun anggaran yang bersangkutan yang menjadi hak pemerintah, dan tidak perlu dibayar kembali oleh pemerintah".

Pendapatan-LO merupakan "Hak pemerintah yang diakui sebagai penambah ekuitas dalam periode pelaporan yang bersangkutan". Sedangkan pendapatan transfer merupakan "Pendapatan berupa penerimaan uang atau hak untuk menerima uang oleh entitas pelaporan dari suatu entitas pelaporan lain yang diwajibkan oleh peraturan perundang-undangan".

Mahmudi (2019, hal 133) menjelaskan bahwa "pendapatan dapat dipahami sebagai hak pemerintah pusat/daerah yang menambah kekayaan bersih yang terjadi akibat transaksi masa lalu".
Tingkat pendapatan setiap negara pasti memiliki perbedaan yang disebabkan perbedaan yang mendasar seperti perbedaan modal, produktivitas, dan tenaga kerja (Andinata dkk, 2018). Pendapatan negara dapat dijadikan dasar untuk mengukur dan menganalisis keadaan perekonomian suatu negara. Pendapatan nasional yang telah dihitung umumnya menggambarkan mengenai keadaan ekonomi yang telah dicapai dalam suatu negara.

Pendapatan negara dikelompokan berdasarkan sumber perolehannya dibagi kedalam dua kelompok yaitu pendapatan pajak dan pendapatan non pajak. Pendapatan pajak diketahui secara umum sebagai penerimaan negara yang berasal dari pembayaran iuran masyarakat kepada pemerintah yang diatur dalam Undang-undang. Apabila ditinjau dari jenisnya, pajak dibedakan menjadi pajak langsung yang berarti jenis pungutan pemerintah yang secara langsung diperoleh dari wajib pajak dan pajak tidak langsung yang berarti pajak yang bebannya dapat dipindah-pindahkan kepada lain pihak.

\section{Analisis Varians (Selisih) Anggaran Pendapatan}

Mahmudi (2019, hal 135) mengemukakan bahwa "analisis varians anggaran pendapatan dilakukan dengan cara menghitung selisih antara realisasi pendapatan dengan yang dianggarkan. Informasi selisih anggaran tersebut sangat membantu pengguna laporan dalam memahami dan menganalisis kinerja pendapatan". Analisis selisih anggaran pendapatan dapat dilakukan menggunakan beberapa langkah berikut ini: pertama, membandingkan antara anggaran dan realisasi pendapatan, jika terdapat selisih kemudian tentukan selisihnya berdasarkan persentase atau nominal. Setelah menentukan kewajaran selisih tersebut, bandingkan selisih tersebut dengan total pendapatan apakah signifikan atau tidak signifikan. Langkah terakhir dari analisis selisih anggaran yaitu cari akar masalah penyebab selisih tersebut terjadi.

\section{Analisis Pertumbuhan Pendapatan}

Mahmudi (2019, hal 137) menyebutkan bahwa "analisis pertumbuhan pendapatan bermanfaat untuk mengetahui apakah pemerintah pusat/daerah dalam tahun anggaran bersangkutan atau selama beberapa periode anggaran, kinerja anggarannya mengalami pertumbuhan pendapatan secara positif atau negatif. Tentunya diharapkan pertumbuhan pendapatan tersebut positif dan kecenderungannya (trend) meningkat". 
"Sebaliknya jika terjadi pertumbuhan yang negatif maka hal itu menunjukkan terjadi penurunan kinerja pendapatan dan harus dicari penyebab penurunannya, apakah karena faktor ekonomi makro yang di luar kendali pemerintah atau karena manajemen keuangan pemerintah yang kurang baik" (Mahmudi, 2019, hal 137).

\section{Analisis Pertumbuhan Ekonomi}

Asumsi pertumbuhan ekonomi merupakan variabel yang dominan menentukan besaran pada komponen pendapatan negara. Pertumbuhan ekonomi merupakan variabel asumsi dasar ekonomi makro yang secara positif berhubungan langsung dengan penerimaan dalam negeri baik itu penerimaan pajak dalam negeri (Pajak Penghasilan, Pajak Pertambahan Nilai, Pajak Bumi dan Bangunan, Cukai, dan Pajak lainnya) maupun Penerimaan Negara Bukan Pajak (PNBP).

\section{Penelitian Terdahulu}

Penelitian sebelumnya yang membahas mengenai analisis kinerja keuangan pemerintah suatu negara selama pandemi COVID-19 cukup banyak dilakukan. Diantaranya penelitian yang dilakukan oleh Nemec \& Spacek (2020) pada laporan keuangan pemerintah Ceko dan Slovakia. Realisasi pendapatan di Ceko menurun sebesar $25 \%$ pada periode Januari-Juli 2020 bila dibandingkan dengan periode yang sama tahun sebelumnya. Penurunan juga terjadi di Slovakia dimana realisasi menurun sebesar $8,18 \%$ pada periode Januari-Juli 2020 bila dibandingkan periode yang sama tahun sebelumnya.

Beberapa penelitian lain yang menunjukkan bahwa kondisi keuangan negara selama pandemi COVID-19 menurun dibanding tahun sebelumnya dilakukan oleh Vakulenko dkk. (2020) pada negara Rusia dan Ukraina, Andrew dkk. (2020) pada negara Australia, Kim (2020) pada negara Korea Selatan, dan de Villiers dkk. (2020) pada negara Afrika Selatan.

Padyanoor (2020) menjelaskan bahwa kebijakan-kebijakan sudah dilakukan pemerintah Indonesia sebagai upaya untuk menggerakkan perekonomian yang terhenti melalui penurunan tarif pajak bahkan pembebasan atas pajak penghasilan. Pajak merupakan sumber pendapatan utama bagi bangsa Indonesia. Kehilangan potensi penerimaan pajak merupakan kerugian yang sangat besar untuk keberlangsungan negara Indonesia.

Beberapa potensi penurunan atas penerimaan pajak seperti perlambatan ekonomi, penurunan konsumsi, dan kebijakan insentif pajak
(Warsito \& Samputra, 2020). Warsito \& Samputra (2020) pemerintah dapat mencoba beberapa kebijakan yang dapat diimplementasikan dalam keadaan pandemi seperti strategi prioritas pajak, strategi dukungan dan pemulihan ekonomi dan lain sebagainya.

Salah satu faktor utama yang dapat dilakukan oleh pemerintah Indonesia dalam upaya pemulihan ekonomi ialah penguatan pada tingkat individu dan entitas usaha. Negara harus memberikan stimulus berupa insentif pajak, bantuan sosial, dan kebijakan yang tepat sebagai upaya antisipasi kerugian ekonomi atas pembatasan aktivitas akibat pandemi COVID- 19 (Hadiwardoyo, 2020).

Hanifah \& Fisabilillah (2021) melakukan penelitian yang bertujuan untuk mengetahui peran dan kebijakan pemerintah pada masa pandemi sebagai upaya menjaga kestabilan perekonomian negara Indonesia. Peran alokasi, distribusi, dan stabilisasi dapat dilakukan pemerintah selama menghadapi pandemi COVID- 19. Ketiga peran tersebut mendapatkan tantangan dalam pengimplementasiannya berupa regulasi dan implementasi di lapangan. Stimulus fiskal diharapkan dapat membangkitkan pertumbuhan ekonomi nasional.

Sanjaya (2020) melakukan analisis kebijakan yang dilakukan pada tingkat daerah provinsi untuk menjawab penyebab menurunnya kondisi perekonomian masyarakat di Provinsi Banten. Penelitiannya menunjukkan bahwa Pemerintah Daerah Provinsi Banten telah menjalankan pengelolaan anggaran sesuai dengan arahan dan kebijakan yang telah diatur oleh pemerintah pusat melalui mekanisme refocusing dan realokasi anggaran pendapatan daerah, belanja daerah, dan pembiayaan daerah secara tepat.

Penelitian mengenai kebijakan fiskal juga dilakukan oleh Juliani (2020) dengan tujuan mengetahui kebijakan fiskal yang dilakukan pemerintah Indonesia selama pandemi COVID- 19. Hasil penelitian menunjukkan bahwa kegiatan dalam penanganan pandemi COVID- 19 dilakukan berdasarkan alokasi dana dalam DIPA.

Junadi dkk (2020) menemukan bahwa pemerintah daerah memiliki alasan bahwa kebijakan refocusing anggaran berdasarkan pada ketentuan dalam Instruksi Presiden tentang refocusing kegiatan, realokasi anggaran, serta pengadaan barang dan jasa dalam rangka percepatan penanganan Covid-19. 


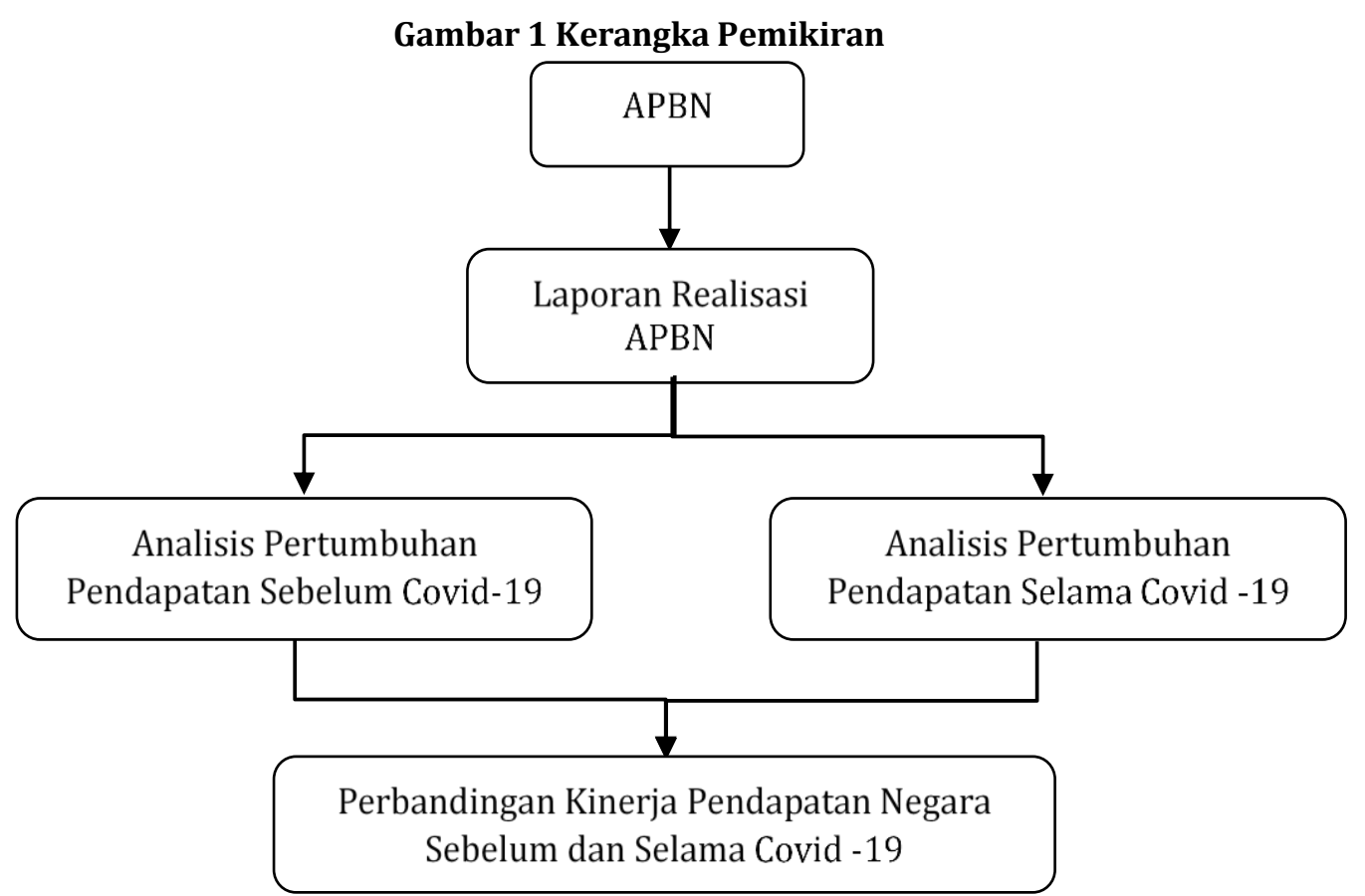

Sumber: Diolah Penulis

Penelitian sebelumnya juga melakukan analisis dampak pandemi Covid-19 pada perkembangan ekonomi makro di Indonesia. Fahrika \& Roy (2020) melakukan penelitian yang bertujuan untuk mengetahui dampak pandemi Covid-19 terhadap perkembangan makro ekonomi di Indonesia dan respons kebijakan yang diambil oleh pemerintah. Kebijakan yang dapat dilakukan pemerintah dalam mengatasi permasalahan ekonomi makro selama pandemi Covid-19 ialah jaring pengaman sosial berupa penambahan dan dukungan dari pembiayaan APBN dan jaring pengaman ekonomi berupa pemberian insentif fiskal dan non fiskal.

Penelitian sebelumnya selain tentang kebijakan dan anggaran selama pandemi Covid-19 ialah penelitian mengenai belanja tak terduga. Dalam keadaan darurat pandemi Covid-19, pemerintah daerah dapat belanja dengan menggunakan belanja tak terduga dalam APBD yang pada kondisi normal jarang dilakukan (Sugiri, 2021).

\section{Kerangka Pemikiran}

Laporan realisasi APBN digunakan oleh pemerintah dan para pengguna laporan keuangan pemerintah untuk menganalisis kinerja pemerintah dalam suatu periode. Secara umum kinerja keuangan pemerintah yang dilihat dari laporan realisasi APBN menunjukkan perkembangan yang positif. Akan tetapi dalam kondisi pertumbuhan ekonomi yang dialami Indonesia selama Covid-19, penulis menyatakan hipotesis bahwa kinerja keuangan pemerintah tahun 2020 selama pandemi Covid-19 berada di bawah tahun-tahun sebelumnya (Gambar 1).

\section{METODOLOGI PENELITIAN}

Data sekunder merupakan data yang akan dianalisis pada penelitian ini. Menurut Sekaran dan Bougie (2017a, hal 133) "data sekunder sangat diperlukan untuk kebanyakan penelitian bisnis dan mengacu pada informasi yang dikumpulkan oleh seseorang, selain peneliti yang melakukan studi saat ini".

Jenis penelitian yang dilakukan ialah metode deskriptif kuantitatif. Menurut Sekaran dan Bougie (2017b, hal 111) "studi deskriptif sering kali didesain untuk mengumpulkan data yang menjelaskan karakteristik orang, kejadian, atau situasi". Obyek yang digunakan dalam penelitian ini ialah Laporan Realisasi APBN Negara Republik Indonesia dari tahun 2016 - 2020.

Statistik deskriptif digunakan sebagai metode analisis data. Sugiyono (2019, hal 206) mendefinisikan "statistik deskriptif sebagai statistik yang digunakan untuk menganalisis data dengan cara mendeskripsikan atau menggambarkan data yang telah terkumpul sebagaimana adanya tanpa bermaksud membuat 
Tabel 2 Analisis Varians (selisih) Anggaran Pendapatan menggunakan APBN 2020 berdasarkan Perpres No 72 Tahun 2020

\begin{tabular}{|c|c|c|c|c|}
\hline \multirow{3}{*}{ Tahun } & \multicolumn{2}{|c|}{ Pendapatan Negara } & \multirow{2}{*}{\multicolumn{2}{|c|}{$\begin{array}{c}\text { Selisih Antara Anggaran dan } \\
\text { Realisasi }\end{array}$}} \\
\hline & Anggaran & Realisasi & & \\
\hline & \multicolumn{2}{|c|}{ (Dalam Triliun) } & Triliun Rupiah & $\%$ \\
\hline 2016 & Rp 1.786 & $\operatorname{Rp} 1.555$ & $\operatorname{Rp}(231,10)$ & $87,06 \%$ \\
\hline 2017 & Rp 1.736 & Rp 1.656 & $\operatorname{Rp}(80,30)$ & $95,37 \%$ \\
\hline 2018 & Rp 1.895 & Rp 1.942 & $\operatorname{Rp} 47,62$ & $102,51 \%$ \\
\hline 2019 & Rp 2.165 & Rp 1.957 & $\operatorname{Rp}(207,90)$ & $90,40 \%$ \\
\hline 2020 & Rp 1.700 & Rp 1.634 & $\operatorname{Rp}(66,36)$ & $96,10 \%$ \\
\hline
\end{tabular}

Sumber: Kementerian Keuangan, 2020

kesimpulan yang berlaku untuk umum atau generalisasi".

Analisis data statistik deskriptif akan dilakukan menggunakan analisis varians (selisih) anggaran pendapatan dan analisis pertumbuhan pendapatan. Mahmudi (2019, hal 135) mengemukakan bahwa "analisis varians anggaran pendapatan dilakukan dengan cara menghitung selisih antara realisasi pendapatan dengan yang dianggarkan". Sedangkan untuk menganalisis pertumbuhan pendapatan, penulis menggunakan pendapat Mahmudi (2017, hal 137) menjelaskan bahwa rumus yang digunakan untuk menentukan pertumbuhan pada pendapatan ialah:

$$
\text { PP Th }-\mathrm{t}=\frac{\text { Pend Th } \mathrm{t}-\text { Pend Th }(\mathrm{t}-1)}{\text { Pend Th }(\mathrm{t}-1)} \times 100 \%
$$

Keterangan:

PP Th-t = Pertumbuhan pendapatan tahun tertentu

Pend Th- $\mathrm{t} \quad=$ Pendapatan tahun tertentu

Pend Th (t-1) = Pendapatan tahun tertentu dikurangi 1 tahun

Analisis ekonomi makro yang digunakan pada penelitian ini ialah analisis pertumbuhan ekonomi. Cara menghitung laju pertumbuhan ekonomi adalah sebagai berikut:

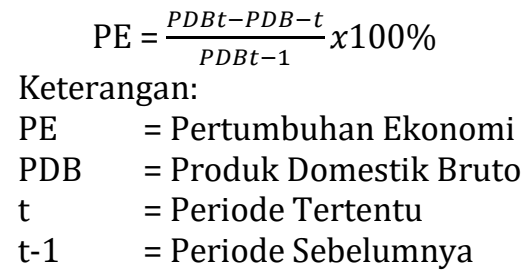

\section{HASIL PENELITIAN}

Penelitian ini menganalisis kinerja pendapatan negara dari tahun 2016 - 2020, secara khusus akan menganalisis kemampuan pemerintah pusat dalam merealisasikan anggaran pendapatan negara yang telah dibuat untuk tahun 2020 pada masa pandemi Covid-19. Kinerja pada dasarnya dianalisis untuk mengetahui kinerja di masa lalu dan merumuskan kebijakan masa mendatang berdasarkan analisis kinerja di masa lalu. Kinerja pendapatan negara dalam penelitian ini dianalisis dengan menggunakan analisis pertumbuhan pendapatan.

\section{Analisis Varians (selisih) Anggaran Pendapatan}

Analisis ini dapat dilakukan dengan menghitung selisih antara anggaran dan realisasi pendapatan negara secara tahunan dari tahun $2016-2020$.

Analisis varians (selisih) anggaran akan dilakukan terhadap APBN 2020 yang terdapat dalam Perpres No 72 Tahun 2020 setelah mengalami perubahan dari Perpres No 78 Tahun 2019 sebelum terjadi pandemi COVID-19 dan Perpres No 54 Tahun 2020 pada awal pandemi Covid-19.

Selisih antara anggaran dan realisasi APBN dari tahun 2016 sampai tahun 2020 yang diperoleh setelah dilakukan perhitungan disajikan pada tabel 2. Analisis varians menunjukkan bahwa dari tahun 2016 - 2018 realisasi APBN selalu mengalami peningkatan, tahun 2016 realisasi sebesar 87,06\%, 2017 meningkat menjadi 95,37\% dan pada tahun 2018 kembali meningkat menjadi 102,51\%. Tetapi hasil sebaliknya didapat pada tahun 2019 dan 2020 yang mengalami penurunan bila dibandingkan tahun 2018 dimana pada tahun 2019 
realisasi APBN menurun menjadi 90,40\% dan tahun 2020 menjadi 96,10\%. Realisasi APBN pada tahun 2020 tetap menunjukkan hasil yang positif sebesar 96,10\% meskipun keadaan global sangat terdampak oleh pandemi Covid-19. Apabila dilihat dalam Rupiah, realisasi APBN dalam kriteria pendapatan negara pada tahun 2020 merupakan hasil realisasi terendah selama 4 tahun terakhir yaitu sebesar Rp1.634 triliun.

Penurunan realisasi pendapatan negara tahun 2019 periode Januari - Agustus secara umum diakibatkan terjadinya perlambatan ekonomi global imbas dari isu perang dagang. Penurunan realisasi pendapatan negara kembali terjadi pada tahun 2020 bila dibandingkan tahun 2018 dikarenakan pandemi Covid-19 yang mengakibatkan prospek ekonomi global juga berada pada kondisi ketidakpastian sebagai dampak dari ketidakpastian pasar keuangan dan perekonomian.

Secara umum kinerja pendapatan negara pada tahun 2020 mengalami penurunan dibandingkan tahun-tahun sebelumnya bila dilihat dari jumlah Rupiah yang dikumpulkan yakni sebesar Rp1.634 triliun. Jumlah tersebut merupakan nilai terendah selama 4 tahun terakhir. Kinerja pendapatan negara pada tahun 2020 dianalisis dengan menggunakan analisis varians (selisih) anggaran pendapatan menunjukkan hasil yang cukup baik dalam keadaan pandemi Covid-19 dengan realisasi sebesar 96,10\% meskipun secara nominal yang dikumpulkan lebih rendah bila dibandingkan tahun sebelumnya.

\section{Analisis Pertumbuhan Pendapatan}

\section{Analisis Pertumbuhan Pendapatan terhadap Realisasi Penerimaan Pajak}

Realisasi penerimaan pajak dari tabel 3 pada tahun 2020 secara umum lebih rendah dari 2019 pada periode yang sama. Penerimaan Pajak - tahun
Artinya jumlah tersebut lebih rendah sebesar 19,67 \% atau sebesar Rp262,08 triliun dari tahun 2019. Secara keseluruhan, penerimaan jenis pajak seperti PPh, PPN \& PPnBM, dan PBB dan Pajak Lainnya juga mengalami penurunan bila dibandingkan tahun lalu.

Penerimaan Pajak Penghasilan (PPh) tahun 2020 mengalami penurunan bila dibandingkan tahun lalu pada periode yang sama dengan tumbuh negatif 22,91\%. Penurunan penerimaan $\mathrm{PPh}$ terjadi baik pada sektor migas maupun non-migas, sektor migas tumbuh negatif $43,84 \%$ dan sektor non-migas tumbuh negatif $21,17 \%$ jika kita bandingkan dengan tahun 2019. Jika dilihat dengan Rupiah, realisasi penerimaan Pajak Penghasilan (PPh) tahun 2020 mengalami penurunan sebesar Rp176,44 triliun jika kita bandingkan dengan tahun 2019.

Penurunan penerimaan pajak tahun 2020 juga terjadi pada kategori PPN \& PPnBM dan PBB dan Pajak Lainnya. Penerimaan PPN \& PPnBM tahun 2020 menurun 15,86\% atau sebesar Rp 84,52 triliun jika kita bandingkan dengan tahun 2019. PBB dan Pajak Lainnya juga mengalami penurunan pada tahun 2020 sebesar 3,92\% atau sebesar Rp1,13 triliun.

\section{Analisis Pertumbuhan Pendapatan terhadap Realisasi Jenis-jenis Pajak Utama}

Pada pembahasan sebelumnya telah dijelaskan bahwa penerimaan pajak pada tahun 2020 secara umum mengalami pertumbuhan negatif bila dibandingkan tahun 2019 pada periode yang sama. Tabel 4 mendeskripsikan analisis lebih mendalam mengenai pertumbuhan realisasi jenisjenis pajak utama.

PPh Pasal 25/29 Orang Pribadi merupakan satu-satunya jenis pajak utama yang masih mampu tumbuh positif sebesar 2,94\% bila dibandingkan

\section{Tabel 3 Realisasi Penerimaan Pajak}

\begin{tabular}{|c|c|c|c|c|}
\hline \multirow{3}{*}{ Uraian } & \multicolumn{2}{|c|}{ Realisasi Anggaran Realisasi Anggaran } & \multicolumn{2}{|c|}{ Pertumbuhan } \\
\hline & Tahun 202 & Tahun 2019 & & \\
\hline & \multicolumn{2}{|c|}{ Triliun Rupiah } & Triliun Rupiah & $\%$ \\
\hline Pajak Penghasilan (PPh) & 593,85 & 770,29 & $(176,44)$ & $-22,91 \%$ \\
\hline - Non-Migas & 560,67 & 711,21 & $(150,54)$ & $-21,17 \%$ \\
\hline - Migas & 33,18 & 59,08 & $(25,90)$ & $-43,84 \%$ \\
\hline PPN \& PPnBM & 448,39 & 532,91 & $(84,52)$ & $-15,86 \%$ \\
\hline PBB dan Pajak Lainnya & 27,73 & 28,86 & $(1,13)$ & $-3,92 \%$ \\
\hline Jumlah & $1.069,98$ & $1.332,06$ & $(262,08)$ & $-19,67 \%$ \\
\hline
\end{tabular}

Sumber: Kementerian Keuangan. 2020

2020 terkumpul sebesar Rp1.069,98 triliun. 
Tabel 4 Realisasi Jenis-jenis Pajak Utama

\begin{tabular}{lcccc}
\hline \multicolumn{1}{c}{ Uraian } & $\begin{array}{c}\text { Realisasi } \\
\text { Anggaran } \\
\text { Tahun 2020 } \\
\text { Triliun }\end{array}$ & $\begin{array}{c}\text { Realisasi } \\
\text { Anggaran } \\
\text { Tahun 2019 }\end{array}$ & \multicolumn{2}{c}{ Pertumbuhan } \\
Triliun & \\
& \multicolumn{2}{c}{ Rupiah } & \% \\
\hline PPh Pasal 21 & 140,78 & 148,63 & $(7,85)$ & $-5,28 \%$ \\
PPh Pasal 25/29 & 169,81 & 267,97 & $(98,16)$ & $-36,63 \%$ \\
- Orang Pribadi & 11,56 & 11,23 & 0,33 & $2,94 \%$ \\
- Badan & 158,25 & 256,74 & $(98,49)$ & $-38,36 \%$ \\
PPh Final & 112,59 & 124,54 & $(11,95)$ & $-9,60 \%$ \\
PPN dalam Negeri & 298,84 & 346,31 & $(47,47)$ & $-13,71 \%$ \\
Pajak atas Impor & 170,42 & 229,64 & $(59,22)$ & $-25,79 \%$ \\
- PPh Pasal 22 Impor & 27,11 & 53,66 & $(26,55)$ & $-49,48 \%$ \\
- PPN Impor & 140,30 & 171,25 & $(30,95)$ & $-18,07 \%$ \\
- PPnBM Impor & 3,00 & 4,73 & $(1,73)$ & $-36,58 \%$ \\
\hline
\end{tabular}

Sumber: Kementerian Keuangan, 2020

pada periode yang sama tahun 2019. Sementara PPh Pasal 25/29 Badan mengalami penurunan yang cukup signifikan dari tahun 2019, pada tahun 2020 turun sebesar 38,36\% atau sebesar Rp98,49 triliun. Penerimaan PPh Pasal 25/29 tahun 2020 mengalami penurunan yang cukup signifikan sebesar 36,63\%. Jika dibandingkan tahun 2019 dan dilihat dengan Rupiah, penurunan penerimaan $\mathrm{PPh}$ Pasal 25/29 tahun 2020 periode Januari- Agustus sebesar Rp98,16 triliun.

Penerimaan pajak pada tahun 2020 juga menurun pada 3 kategori. Penerimaan PPh Pasal 21 tahun 2020 menurun 5,28\% atau sebesar Rp 7,85 triliun dibanding 2019. Dibandingkan 2019, $\mathrm{PPh}$ Final juga terjadi penurunan, yakni sebesar 9,60\% atau sebesar Rp11,95 triliun. PPN dalam negeri tahun 2020 juga terjadi penurunan dibandingkan 2019, yaitu sebesar 13,71\% atau sebesar Rp47,47 triliun.

Kategori lain yang juga mengalami pertumbuhan negatif pada tahun 2020 ialah Pajak atas impor. Penerimaan Pajak atas impor pada tahun 2020 mengalami penurunan bila dibandingkan tahun sebelumnya pada periode yang sama dengan tumbuh negatif 25,79\%. Penurunan penerimaan pajak atas impor terjadi pada semua sektor yaitu PPh Pasal 22 Impor, PPN Impor, dan PPnBM Impor. Pada tahun $2020 \mathrm{PPh}$ Pasal 22 Impor tumbuh negatif 49,48\%, PPN Impor tumbuh negatif 18,07\%, dan PPnBM tumbuh negatif $36,58 \%$ bila dibandingkan tahun 2019 pada periode yang sama. Jika dilihat dengan Rupiah, realisasi penerimaan Pajak atas impor tahun 2020 mengalami penurunan sebesar Rp59,22 triliun.

Jika kinerja pendapatan negara tahun 2020 dibandingkan dengan tahun 2019 dilihat dari sisi realisasi penerimaan pajak secara umum menurun sebesar Rp262,08 triliun atau sebesar 19,67\%.

\section{Analisis Pertumbuhan Pendapatan terhadap Realisasi PNBP}

Realisasi pada tabel 5 menyajikan bahwa seluruh kategori yang terdapat pada Penerimaan Negara Bukan Pajak mengalami penurunan pada tahun 2020. Pada kategori penerimaan SDA pada tahun 2020 mengalami penurunan cukup besar bila dibandingkan tahun 2019 dengan periode yang sama sebesar negatif $36,50 \%$. Penurunan penerimaan SDA tahun 2020 dibanding tahun 2019 terjadi baik pada sektor migas maupun nonmigas, sektor migas tumbuh negatif $42,11 \%$ dan sektor non-migas tumbuh negatif $16,48 \%$. Jika dilihat dengan Rupiah, realisasi penerimaan SDA tahun 2020 mengalami penurunan sebesar Rp56,25 triliun bila dibandingkan tahun 2019.

Penurunan juga terjadi pada PNBP lainnya dan pendapatan dari kekayaan negara yang dipisahkan. Pada tahun 2020 yang dibandingkan dengan tahun 2019, pendapatan dari kekayaan negara yang dipisahkan tumbuh negatif $18,15 \%$ atau sebesar Rp14,65 triliun, PNBP lainnya tumbuh negatif 9,59\% atau sebesar Rp11,71 triliun. Satusatunya komponen dalam PNBP yang mengalami pertumbuhan positif ialah pendapatan BLU yakni sebesar 33,49\% atau sebesar Rp16,11 triliun.

Kinerja pendapatan negara dilihat dari sisi realisasi Penerimaan Negara Bukan Pajak (PNBP) pada tahun 2020 mengalami penurunan sebesar $16,42 \%$ bila dibandingkan tahun 2019 pada periode yang sama. Jika dilihat dengan Rupiah dan 
Tabel 5 Realisasi PNBP

\begin{tabular}{lcccc}
\hline \multicolumn{1}{c}{ Uraian } & Realisasi TA 2020 & Realisasi TA 2019 & \multicolumn{2}{c}{ Pertumbuhan } \\
& Triliun Rupiah & Triliun Rupiah & Triliun Rupiah & $\%$ \\
\hline A. Penerimaan SDA & 97,84 & 154,09 & $(56,25)$ & $-36,50 \%$ \\
1. Migas & 69,71 & 120,41 & $(50,70)$ & $-42,11 \%$ \\
2. Non Migas & 28,12 & 33,67 & $(5,55)$ & $-16,48 \%$ \\
B. Pendapatan dari & & & & \\
Kekayaan Negara yang & & & & \\
Dipisahkan & 66,08 & 80,73 & $(14,65)$ & $-18,15 \%$ \\
C. PNBP Lainnya & 110,41 & 122,12 & $(11,71)$ & $-9,59 \%$ \\
D. Pendapatan BLU & 64,21 & 48,10 & 16,11 & $33,49 \%$ \\
Jumlah PNBP & 338,54 & 405,04 & $(66,50)$ & $-16,42 \%$ \\
\hline
\end{tabular}

dibandingkan tahun 2019, realisasi Penerimaan Negara Bukan Pajak (PNBP) tahun 2020 mengalami penurunan sebesar Rp66,50 triliun.

Hasil penelitian ini sejalan dengan penelitian Heald \& Hodges (2020) yang menunjukkan bahwa terjadi penurunan pendapatan sebesar $12 \%$ pada pemerintah negara Inggris periode April-Juni bila dibandingkan dengan periode yang sama tahun sebelumnya.

\section{Analisis Pertumbuhan Ekonomi}

Tabel 6 menunjukkan perkembangan pertumbuhan ekonomi negara Republik Indonesia pada tahun 2017 - 2020. Persentase pertumbuhan ekonomi dari tahun 2017 - 2019 periode triwulan II selalu mengalami peningkatan, pada tahun 2017 meningkat sebesar 5,07\%, tahun 2018 meningkat sebesar 5,17\%, dan tahun 2019 meningkat sebesar 5,02\%. Tetapi hasil sebaliknya ditunjukkan pada tahun 2020 yang mengalami penurunan sebesar negatif 2,07\% bila dibandingkan tahun 2019 pada periode yang sama.

\section{Pembahasan}

Realisasi APBN dalam kriteria pendapatan negara pada tahun 2020 menunjukkan hasil yang cukup baik dengan realisasi sebesar 96,10\% meskipun realisasi tersebut merupakan hasil realisasi terendah selama 4 tahun terakhir bila dilihat dari jumlah Rupiah yang dikumpulkan. Apabila kita lihat analisis pendapatan negara secara lebih spesifik, secara umum hampir seluruh kriteria penerimaan negara baik yang berasal dari pajak maupun non pajak menunjukkan penurunan pada tahun 2020 bila dibandingkan periode yang sama tahun sebelumnya.

Sumber-sumber penerimaan pajak yang mengalami penurunan ialah $\mathrm{PPh}$ pasal 21, $\mathrm{PPh}$ pasal 25/29 badan, PPh final, PPN dalam negeri, dan pajak atas impor. Jumlah penurunan realisasi penerimaan pajak sebesar $-19,67 \%$ atau sekitar Rp262,08 triliun pada tahun 2020 bila dibandingkan periode yang sama tahun sebelumnya.

Satu-satunya penerimaan pajak yang mampu tumbuh positif ialah PPh pasal 25/29 orang pribadi dengan pertumbuhan 2,94\% atau sekitar Rp0,33 triliun. Pertumbuhan positif PPh pasal 25/29 orang pribadi dipengaruhi oleh WP OP mengalami peningkatan dalam hal kepatuhan yang dikelola dan diawasi oleh Direktorat Jenderal Pajak.

Realisasi Penerimaan Negara Bukan Pajak (PNBP) juga menunjukkan hasil serupa dimana terjadi penurunan pada hampir semua kriteria tahun 2020 bila dibandingkan tahun sebelumnya pada periode yang sama. Sumber-sumber PNBP yang mengalami penurunan ialah penerimaan SDA migas (minyak bumi dan gas alam), penerimaan SDA non migas, pendapatan dari kekayaan negara yang dipisahkan, dan PNBP lainnya. Penurunan

\section{Tabel 6 Analisis Pertumbuhan Ekonomi}

\begin{tabular}{cccc}
\hline Tahun & $\begin{array}{c}\text { PDB Rill } \\
\text { (miliar Rp) }\end{array}$ & $\begin{array}{c}\text { Pertumbuhan Ekonomi } \\
\text { (miliar Rp) }\end{array}$ & \% \\
\hline 2017 & Rp 9.912.928,10 & Rp 478.314,70 & $5,07 \%$ \\
2018 & Rp $10.425 .397,30$ & $\operatorname{Rp~} 512.469,20$ & $5,17 \%$ \\
2019 & Rp $10.949 .243,70$ & Rp $523.846,40$ & $5,02 \%$ \\
2020 & Rp $10.722 .400,00$ & $\operatorname{Rp~}(226.843,70)$ & $-2,07 \%$ \\
\hline
\end{tabular}


terbesar terjadi pada sektor penerimaan SDA migas sebesar $42,11 \%$ atau Rp50,70 triliun pada tahun 2020 bila dibandingkan periode yang sama tahun sebelumnya.

Satu-satunya PNBP yang tumbuh positif ialah pendapatan BLU dengan pertumbuhan sebesar 33,49\% atau sekitar Rp16,11 triliun. Pertumbuhan positif pendapatan BLU sangat dipengaruhi pertumbuhan dari pendapatan dana perkebunan kelapa sawit sebesar 205,72\% periode Januari Agustus tahun 2020 bila dibandingkan periode yang sama tahun sebelumnya. Pertumbuhan positif dana perkebunan kelapa sawit menunjukkan bahwa industri kelapa sawit tidak terdampak pandemi Covid-19, namun hal tersebut perlu dibuktikan melalui penelitian ilmiah dengan metode yang relevan.

\section{KESIMPULAN DAN SARAN}

\section{Kesimpulan}

Berdasarkan hasil penelitian dan pembahasan yang telah disajikan sebelumnya, maka dapat disimpulkan bahwa kinerja pendapatan negara selama pandemi Covid-19 tahun 2020 mengalami penurunan yang cukup signifikan jika dibandingkan dengan tahun 2019 pada periode yang sama. Realisasi pendapatan negara selama Covid-19 tahun 2020 tumbuh negatif 16,53\% atau terjadi penurunan realisasi sebesar Rp323,61 triliun jika kita bandingkan dengan tahun 2019.

Bila realisasi pendapatan negara dilihat lebih dalam, penurunan realisasi terjadi baik pada realisasi penerimaan pajak maupun realisasi Penerimaan Negara Bukan Pajak (PNBP). Realisasi penerimaan pajak pada tahun 2020 tumbuh negatif $19,67 \%$ atau terjadi penurunan realisasi sebesar Rp262,08 triliun dan realisasi PNBP tumbuh negatif $16,42 \%$ atau terjadi penurunan realisasi sebesar Rp66,50 triliun jika kita bandingkan dengan tahun 2019 pada periode yang sama. Penurunan kinerja pendapatan negara sejalan dengan dugaan awal penulis setelah melihat respon pemerintah dengan menurunkan target anggaran pendapatan negara yang ada pada Undang-undang No Tahun 2019 tentang APBN sebanyak dua kali melalui Perpres No 54 dan 72 Tahun 2020.

Penurunan realisasi pendapatan negara pada tahun 2020 sangat dipengaruhi oleh faktor ekonomi makro yakni faktor pertumbuhan ekonomi yang mengalami penurunan sebesar negatif 2,07\% pada tahun 2020 bila dibandingkan periode yang sama tahun sebelumnya. Selama periode tahun 2017 - 2020, penurunan pertumbuhan ekonomi baru terjadi pada tahun 2020 dimana salah satu penyebabnya adalah terjadinya pandemi Covid-19 yang juga mempengaruhi perekonomian global.

Secara umum kinerja pendapatan negara pada tahun 2020 mengalami penurunan dibandingkan tahun-tahun sebelumnya bila dilihat dari jumlah Rupiah yang dikumpulkan yakni sebesar Rp1.634 triliun. Jumlah tersebut merupakan nilai terendah selama 4 tahun terakhir. Akan tetapi, meskipun dalam keadaan pandemi Covid-19 kinerja pendapatan negara pada tahun 2020 dianalisis dengan menggunakan analisis varians (selisih) anggaran pendapatan menunjukkan hasil yang cukup baik dengan realisasi sebesar 96,10\%.

\section{Saran}

Pemerintah harus melakukan langkah-langkah yang lebih komprehensif dalam upaya-upaya meningkatkan realisasi pendapatan negara seperti fokus pada pengendalian dan penghentian wabah Covid-19, pemberian insentif bagi mereka yang terdampak, dan penerapan kebijakan yang mendukung penguatan kondisi ekonomi.

\section{IMPLIKASI DAN KETERBATASAN}

Penanganan dan pengendalian serta penghentian wabah Covid-19 merupakan hal utama untuk melakukan percepatan pertumbuhan perekonomian nasional. Pemberian insentif bagi yang terdampak wabah untuk menjaga daya beli masyarakat dan penerapan kebijakan ekonomi yang tepat juga perlu dilakukan. Hal tersebut merupakan implikasi dari penelitian ini. Keterbatasan dari penelitian ini ialah analisis dilakukan hanya pada realisasi pendapatan negara saja berupa realisasi penerimaan pajak secara umum, realisasi jenis-jenis pajak utama dan realisasi Pendapatan Negara Bukan Pajak (PNBP) serta analisis pertumbuhan ekonomi secara umum. Untuk itu diperlukan penelitian lebih lanjut dengan menganalisis realisasi belanja negara dan aspek lainnya yang ada pada APBN serta pengaruh pandemi Covid-19 terhadap pendapatan negara secara lebih mendalam.

\section{PENGHARGAAN}

Penelitian ini dapat terlaksana atas bantuan dari berbagai profesi dan rekan kerja. Ucapan terima kasih penulis sampaikan kepada semua elemen yang telah membantu dalam semua proses penelitian ini. 


\section{DAFTAR PUSTAKA}

Andinata, C, P., Adenan, M., \& Jumiati, A. (2018). Analisis pendapatan nasional di negaranegara anggota ASEAN. Jurnal Ekonomi Ekuilibrium, 2(1), 31 - 44.

Andrew, I. dkk. (2020). Australia's covid-19 public budgeting response: the straitjacket of neoliberalism. Journal of Public Budgeting, Accounting \& Financial Management, 32 (5), 759-770.

Baridwan, Z. (2012). Analisis faktor-faktor yang mempengaruhi penumpukan penyerapan anggaran belanja pada akhir tahun anggaran. Yogyakarta: Universitas Gadjah Mada.

de Villiers, C., Cerbone, D., \& Van Zijl, W. (2020). The South African Government's response to covid-19. Journal of Public Budgeting, Accounting \& Financial Management, 32(5), 797-811.

Fahrika, A, I., \& Roy, J. (2020). Dampak pandemi covid 19 terhadap perkembangan makro ekonomi di indonesia dan respon kebijakan yang ditempuh. INOVASI: Jurnal Ekonomi Keuangan dan Manajemen, 16 (2), 206 - 2013.

Hadiwardoyo, W. (2020). Kerugian ekonomi nasional akibat pandemi covid- 19. Baskara: Journal of Business \& Entrepreneurship, 2(2), $83-92$.

Halim, A \& Kusufi, M. S. (2014). Akuntansi sektor publik-akuntansi keuangan daerah. Jakarta: Salemba Empat

Hanifah, N., \& Fisabilillah, L, W, P. (2021). Peran dan kebijakan pemerintah indonesia di masa pandemi covid-19. WELFARE: Jurnal Ilmu Ekonomi, 2(1), 9 - 19.

Heald, D. \& Hodges, R. (2020). The accounting, budgeting and fiscal impact of covid-19 on the United Kingdom. Journal of Public Budgeting, Accounting \& Financial Management, 32(5), 785-795.

Juliani, H. (2020). Kebijakan fiskal: anggaran belanja negara untuk perlindungan sosial dalam penanganan pandemi covid-19. Administrative Law and Governance Journal, 3 (4), 595 - 616.

Junadi, M., Sukarna, K., Arifin, Z., \& Soegianto. (2020). Kebijakan refocusing anggaran belanja daerah dalam penanganan pandemi covid-19. Halu Oleo Law Review, 4 (2), 145 156.
Kim, B. H. (2020). Budgetary responses to covid19: the case of South Korea. Journal of Public Budgeting, Accounting \& Financial Management, 32(5), 939-947.

Kuswoyo, I. D. (2012). Analisis atas faktor-faktor yang menyebabkan terkonsentrasinya penyerapan anggaran belanja di akhir tahun anggaran (studi pada satuan kerja di wilayah KPPN Kediri. Yogyakarta: Universitas Gadjah Mada.

Mahmudi. (2019). Analisis laporan keuangan pemerintah daerah. Yogyakarta: UPP STIM YKPN

Nemec, I \& Spacek, D. (2020). The covid-19 pandemic and local government finance: Czechia and Slovakia. Journal of Public Budgeting, Accounting \& Financial Management, 32(5), 837-846.

Nugroho, M. A., \& Ananda, C. F. (2012). Analisis faktor-fator yang menyebabkan penumpukan pencairan dana apbn di akhir tahun (studi kasus di KPPN Malang). Jurnal Ilmiah Mahasiswa FEB, 1(2).

Padyanoor, A. (2020). Kebijakan pajak Indonesia menanggapi krisis covid- 19: manfaat bagi wajib pajak. E-Jurnal Akuntansi, 30(9), 2216 2230.

Peraturan Presiden No 54 Tahun 2020 tentang Perubahan Atas Peraturan Presiden Nomor 54 Tahun 2020 tentang Perubahan Postur Dan Rincian Anggaran Pendapatan Dan Belanja Negara Tahun Anggaran 2020. Jakarta.

Peraturan Presiden No 71 Tahun 2010 tentang Standar Akuntansi Pemerintahan. Jakarta.

Peraturan Presiden No 72 Tahun 2020 Tentang perubahan atas peraturan presiden nomor 54 tahun 2020 tentang perubahan postur dan rincian anggaran pendapatan dan belanja negara tahun anggaran 2020. Jakarta.

Peraturan Presiden No 78 Tahun 2019 Tentang Rincian Anggaran Pendapatan dan Belanja Negara Tahun Anggaran 2020. Jakarta.

Rahim, A. \& Saputra, H. (2018). Exploratory faktor analysis (EFA) pada penyerapan anggaran pendapatan dan belanja negara (APBN) tahun 2017 di Provinsi Sumatera Barat. Indonesian Treasury Review: Jurnal Perbendaharaan, Keuangan Negara dan Kebijakan Publik, 3(3), 236-254. 
Sanjaya, N. (2020). Kebijakan penganggaran daerah di masa pandemi covid- 19 (studi kasus pada pemerintah daerah Provinsi Banten). Jurnal Ilmu Administrasi, 17 (2), 273 $-290$.

Sekaran, U. \& Bougie, R. (2017.a). Metode penelitian untuk bisnis buku I. Jakarta: Salemba Empat.

Sekaran, U. \& Bougie, R. (2017.b). Metode penelitian untuk bisnis buku II. Jakarta: Salemba Empat

Setyawan, A. (2017). Analisis keterlambatan penyerapan anggaran belanja satuan kerja kementerian/lembaga di wilayah pembayaran KPPN Bojonegoro tahun anggaran 2015. Thesis. Surabaya: Fakultas Ekonomi, Universitas Airlangga.

Siswanto, A. D., \& Rahayu, S. L. (2010). Faktorfaktor penyebab rendahnya penyerapan belanja kementerian/lembaga TA 2010. Policy Paper Pusat Kebijakan APBN.

Sugiri, D. (2021). Perlakuan akuntansi belanja tak terduga pada pemerintah daerah akibat pandemi covid-19. Jurnal Ilmiah Akuntansi dan Keuangan, 10 (1), 58 - 68.

Sugiyono. (2019). Metode penelitian kuantitatif kualitatif dan $R \& D$. Bandung: Alfabeta.

Sulistyo, A. T. (2018). Analisis kinerja keuangan pemerintah Provinsi Kalimantan Timur.
Indonesian Treasury Review: Jurnal Perbendaharaan, Keuangan Negara dan Kebijakan Publik, 3(1), 43-59.

Undang-Undang No 17 Tahun 2003 Tentang Keuangan Negara. Jakarta.

Undang-Undang No 20 Tahun 2019 Tentang Anggaran Pendapatan dan Belanja Negara Tahun Anggaran 2020. Jakarta.

Vakulenko, V., Khodachek, I., \& Bourmistorv, A. (2020). Ideological and financial spaces of budgetary responses to covid-19 lockdown strategies: comparative analysis of Russia and Ukraine. Journal of Public Budgeting, Accounting \& Financial Management, 32(5), 865-874.

Warsito \& Samputra, P, L. (2020). Potensi penurunan pajak dan strategi kebijakan pajak untuk mengantisipasi dampak pandemi covid- 19: perspektif ketahanan nasional. Jurnal Ekonomi \& Kebijakan Publik, 11(2), 93 108.

Zukhri, N. (2020). Kinerja keuangan Provinsi Kepulauan Bangka Belitung ditinjau dari derajat kemandirian, ketergantungan, dan desentralisasi fiskal. Indonesian Treasury Review: Jurnal Perbendaharaan, Keuangan Negara dan Kebijakan Publik, 5(2), 143-149. 